\title{
A role for heterotrimeric GTP-binding proteins and ERK1/2 in insulin-mediated, nitric-oxide-dependent, cyclic GMP production in human umbilical vein endothelial cells
}

Received: 22 July 2004 / Accepted: 8 October 2004 / Published online: 1 March 2005

(C) Springer-Verlag 2005

\begin{abstract}
Aims/hypothesis: Insulin is known to stimulate endothelial nitric oxide synthesis, although much remains unknown about the intracellular mechanisms involved. This study aims to examine, in human endothelial cells, the specific contribution of heterotrimeric $\mathrm{G}_{\mathrm{i}}$ proteins and extracellular signal-regulated protein kinases $1 / 2($ ERK1/2) in insulin signalling upstream of nitric-oxide-dependent cyclic GMP production. Methods: Human umbilical vein endothelial cells were treated with $1 \mathrm{nmol} / \mathrm{l}$ insulin in the presence or absence of inhibitors of tyrosine kinases (erbstatin), $\mathrm{G}_{\mathrm{i}}$ proteins (pertussis toxin) or ERK1/2 (PD098059 or U0126), and nitric oxide production was examined by quantification of intracellular cyclic GMP. Activation/phosphorylation of ERK1/2 by insulin was examined by immunoblotting with specific antibodies, and direct association of the insulin receptor with $\mathrm{G}_{\mathrm{i}}$ proteins was examined by immunoprecipitation. Results: Treatment of cells with a physiological concentration of insulin $(1 \mathrm{nmol} / \mathrm{l})$ for $5 \mathrm{~min}$ increased nitric-oxide-dependent cyclic GMP accumulation by 3.3fold, and this was significantly inhibited by erbstatin. Insulin-stimulated cyclic GMP production was significantly reduced by pertussis toxin and by the inhibitors of ERK $1 / 2$, PD098059 and U0126. Immunoblotting indicated that insulin stimulated the phosphorylation of ERK1/2 after $5 \mathrm{~min}$ and $1 \mathrm{~h}$, and that this was completely abolished by pertussis toxin, but insensitive to the nitric oxide synthase inhibitor L-NAME. No direct interaction of the insulin
\end{abstract}

\footnotetext{
O. Konopatskaya · A. C. Shore $\cdot$ J. E. Tooke

J. L. Whatmore $(\bowtie)$

Institute for Biomedical and Clinical Science,

Peninsula Medical School,

Exeter, EX1 2LU, UK

e-mail: jackie.whatmore@pms.ac.uk

Tel.: +44-1392-403091

Fax: +44-1392-262944

O. Konopatskaya

Department of Physiology,

School of Medical Sciences,

University of Bristol,

Bristol, UK
}

receptor $\beta$ with $\mathrm{G}_{\mathrm{i}_{\alpha} 2}$ could be demonstrated by immunoprecipitation. Conclusions/interpretation: This study demonstrates, for the first time, that nitric oxide production induced by physiologically relevant concentrations of insulin, is mediated by the post-receptor activation of a pertussissensitive GTP-binding protein and subsequent downstream activation of the ERK1/2 cascade.

Keywords Cyclic GMP · ERK1/2 · Insulin · Nitric oxide · Pertussis toxin

Abbreviations ECGS: endothelial growth factor supplement - eNOS: endothelial nitric oxide synthase · ERK1/2: extracellular signal-regulated protein kinases $1 / 2$. G protein: GTP-binding protein - IR $\beta$ : insulin receptor $\beta$ subunit - MAPK: mitogen-activated protein kinase - MTT: 3-[4,5]Dimethylthiazol-2,5diphenyltetrazolium bromide . NOS: nitric oxide synthase - PI3K: phosphatidylinositol 3-kinase - PMSF: phenylmethylsulphonylfluoride · PTX: pertussis toxin

\section{Introduction}

Insulin is an essential hormone that regulates metabolism, growth and differentiation. The biological actions of insulin are initiated when insulin binds to the extracellular domain of its cognate cell surface receptor. The subsequent activation of the intracellular tyrosine protein kinase activity of the receptor triggers autophosphorylation of the $\beta$-subunit of the receptor as well as phosphorylation of a number of intracellular insulin receptor substrates, including IRSs and Shc. This gives rise to the activation of Ras and phosphatidylinositol 3-kinase (PI3K), and hence to the activation of a number of serine/threonine protein kinases. Many of these kinases are arranged in cascades, including a cascade that results in activation of mitogen-activated protein kinase (MAPK) and another that may result in activation of protein kinase B (Akt) [1].

As well as being present on traditional insulin-responsive cells, i.e. adipocytes and skeletal muscle, insulin re- 
ceptors have been demonstrated on endothelial cells of both large and small blood vessels $[2,3]$. Insulin has been shown to strongly influence the function of the vascular endothelium and in vitro studies indicate that its functions include increases in amino acid transport, gene expression and enhancement of nitric oxide release $[4,5]$. A number of studies have also provided convincing evidence that, in addition to its metabolic effects, insulin has nitric-oxide-dependent vasodilator actions in vivo [6-8]. This is supported by the observation that endothelial nitric oxide synthase (eNOS) knockout mice are insulin-resistant compared to the wild type [9], and that the vascular action of insulin is altered in insulin-resistant states, such as diabetes and obesity [10].

Despite extensive investigation, much remains unknown about how insulin exerts its effect on nitric oxide synthesis. In vitro studies in cultured human endothelial cells have demonstrated that the signalling pathways activated during insulin-stimulated nitric oxide production include the insulin receptor tyrosine kinase, phosphatidylinositol 3-kinase (PI3K) and Akt $[5,11]$, molecules which these pathways share with the metabolic actions of insulin, such as translocation of the insulin-sensitive glucose transporter GLUT4. In addition, insulin has also been reported to regulate the Ras/MAPK cascade, specifically the extracellular signalregulated protein kinases1/2 (ERK1/2) isoforms that are ubiquitously expressed and are activated by dual-specificity MAPK kinases (MEK1/MEK2) [12]. MAPK activation in response to insulin is classically considered to be associated with regulation of gene expression and cell proliferation, but the possibility of a MAPK contribution to insulin-induced nitric oxide synthesis has not been investigated. This possibility is supported by the observation that the ERK1/2 signalling pathway is involved in nitric oxide production in human endothelial cells stimulated by other agonists including adenosine [13].

Endothelium-derived nitric oxide is synthesised by the endothelial calcium/calmodulin-dependent form of nitric oxide synthase (eNOS) that is one of three isoenzymes that convert L-arginine to L-citrulline, forming nitric oxide in the process. Activation of nitric oxide synthase (NOS) and release of nitric oxide results in stimulation of a soluble guanylyl cyclase leading to a profound increase of cyclic GMP levels within target cells and thus vasodilatation [14]. The generation of nitric oxide represents a common component of the signal transduction pathways of a number of agonists (e.g. acetylcholine, serotonin, ATP, bradykinin, histamine) that act via binding to receptors coupled to heterotrimeric GTP-binding proteins ( $\mathrm{G}$ proteins). Agonist binding to the receptor leads to exchange of GDP to GTP, resulting in dissociation of $\alpha$-GTP and $\beta \gamma$-subunits [15]. Both the $\alpha$ - and $\beta \gamma$-subunits can transduce several events in cells. Previously it has been reported that pertussis toxin (PTX), which ADP-ribosylates the $\alpha$-subunit of members of the $G_{i} / G_{o}$ family and uncouples them from receptors, inhibited a number of insulin-stimulated events, such as glucose transport and metabolism in the insulin target cells $[16,17]$. In addition, $\mathrm{G}$ proteins sensitive to pertussis toxin have been reported to be involved in nitric oxide synthesis triggered by other agonists including endothelin [18] and acetylcholine [19]. However, the involvement of pertussissensitive G-proteins in insulin-mediated nitric oxide responses of human endothelial cells remains unknown.

This study was designed to examine the specific contribution of PTX-sensitive G-proteins and ERK1/2 in the intracellular signalling pathways activated during insulin stimulation of nitric oxide synthesis in human endothelial cells. We provide, for the first time, evidence that nitric oxide production induced by physiologically relevant concentrations of insulin is mediated by the post-receptor activation of G-proteins and determined by a downstream initiation of the MAPK cascade.

\section{Materials and methods}

Materials Unless stated otherwise, materials were obtained from Sigma Chemicals (Poole, UK).

Endothelial cell culture Human umbilical cords were obtained within $12 \mathrm{~h}$ of birth from normal pregnancies. The anonymous collection of umbilical cords for this project was approved by the North and East Devon Medical Research Ethics Committee (study 1301). Human umbilical vein endothelial cells were isolated from the vein by collagenase $(0.3 \mathrm{mg} / \mathrm{ml})$ digestion [20] and cultured in medium 199 (M199) containing $5 \mathrm{mmol} / 1$ glutamine, $20 \%$ (v/v) fetal bovine serum, $0.05 \mathrm{mg} / \mathrm{ml}$ gentamicin, $20 \mu \mathrm{g} / \mathrm{ml}$ endothelial growth factor supplement (ECGS) and $90 \mu \mathrm{g} / \mathrm{ml}$ heparin at $37^{\circ} \mathrm{C}$ in $5 \% \mathrm{CO}_{2} /$ air. Confluent monolayers were trypsinised (trypsin-EDTA, $0.1-0.02 \% \mathrm{w} / \mathrm{v}$ ), and the cells resuspended in M199 and cultured for the cyclic GMP assay on gelatine $(1 \%, w / v)$-coated $24-w e l l$ plates. For immunoblotting, cells were grown on $21-\mathrm{cm}^{2}$ plastic Petri dishes (Greiner, Gloucester, UK). The identity of endothelial cells in culture was confirmed by the presence of the typical "cobblestone" morphology and by the expression of von Willebrand factor, PECAM and ACE as determined by immunocytochemical staining and western blotting. All cells were used at passage one at $85-90 \%$ confluency. Cell viability during passage procedure was routinely assessed by trypan blue exclusion.

Nitric oxide production Nitric oxide production was assessed by quantification of intracellular cyclic GMP levels, which allowed a functional cellular response to be studied. Cells were grown on 24-well plates in supplemented M199 in the presence or absence of inhibitors as indicated. Cells were then washed and pre-incubated for $15 \mathrm{~min}$ in Krebs buffer $\left(37^{\circ} \mathrm{C}\right)$, containing $100 \mu \mathrm{mol} / 1 \mathrm{~L}$-arginine and $0.5 \mathrm{mmol} /$ 1 of the phosphodiesterase inhibitor, 3-isobutyl-1-methylxanthine. Pre-incubation media were removed and in some experiments cells were additionally challenged with $1 \mathrm{nmol} /$ 1 human recombinant insulin (Calbiochem, Nottingham, UK) in Krebs solution for $5 \mathrm{~min}$. Stimulation was terminated 
by treatment of cells with $0.1 \mathrm{~N} \mathrm{HCl}$ on ice for $60 \min (300 \mu \mathrm{l}$ per well). The $\mathrm{HCl}$ cell extract was assayed for cyclic GMP accumulation by radioimmunoassay following acetylation (Amersham, Little Chalfont, UK). The sensitivity of the assay is less than $2 \mathrm{fmol} / 1$ per $50 \mu \mathrm{l}$; the intra-assay coefficient of variation is $9.8 \%(n=6)$. Cell protein was assayed with Bradford reagent [21] after cell solubilisation in $1 \mathrm{~mol} / 1$ $\mathrm{NaOH}$. The intracellular cyclic GMP concentration was initially expressed in fmol/ $\mu \mathrm{g}$ protein. Due to the variation in increases in cyclic GMP levels between cell populations, intracellular cyclic GMP concentration is presented in the text as percentage of insulin-stimulated cyclic GMP content.

Immunoblotting For the examination of total and phosphorylated levels of ERK1/2, HUVECs were starved of fetal bovine serum and ECGS for $16 \mathrm{~h}$ and then treated with insulin $(1 \mathrm{nmol} / \mathrm{l})$ and/or drugs for times indicated. This period of serum starvation is similar to that used by other investigators [13, 22], and was necessary to reduce baseline activation of ERK1/2 by components in the serum. Similar results were obtained with shorter periods of serum starvation (i.e. $4 \mathrm{~h}$ ), however, the baseline levels of phosphorylated ERK1/2 were higher. For total and phosphorylated eNOS cells were serum-starved for $4 \mathrm{~h}$. For the examination of total $\mathrm{G}_{\alpha}$ i2 cells were not serum-starved. HUVECS were then washed twice with ice-cold PBS and lysed for $1 \mathrm{~min}$ in lysis buffer: $50 \mathrm{mmol} / \mathrm{l}$ Tris $(\mathrm{pH} 8.0$ ), $150 \mathrm{mmol} / \mathrm{l} \mathrm{NaCl}$, $1 \mathrm{mmol} / \mathrm{l}$ EGTA (pH 8.0), $100 \mathrm{mmol} / \mathrm{l} \mathrm{NaF}, 100 \mathrm{mmol} / \mathrm{l}$ $\mathrm{MgCl}_{2}, 10 \% \mathrm{w} / \mathrm{v}$ glycerol, $1 \% \mathrm{w} / \mathrm{v}$ Triton $\mathrm{X}_{100}, 1 \mathrm{mmol} / 1$ phenylmethylsulphonylfluoride (PMSF), $1 \mathrm{mmol} / 1$ sodium orthovanadate, and $50 \mu \mathrm{l} / \mathrm{ml}$ of protease inhibitor cocktail consisting of $20 \mu \mathrm{g} / \mathrm{ml}$ leupeptin, $20 \mu \mathrm{g} / \mathrm{ml}$ pepstatin A, $200 \mu \mathrm{g} / \mathrm{ml}$ benzoyl-L-arginine methyl ester, $200 \mu \mathrm{g} / \mathrm{ml}$ $p$-tosyl-L-arginine methyl ester, $200 \mu \mathrm{g} / \mathrm{ml}$ trypsin inhibitor, $200 \mu \mathrm{g} / \mathrm{ml} \mathrm{L}$-1-tosylamide-2-phenylethylchloromethyl ketone and $200 \mu \mathrm{g} / \mathrm{ml}$ aprotinin. The lysates were subjected to one cycle of freezing/thawing, mild ultrasonication for $5 \mathrm{~min}$ in a sonicleaner and protein content measurement. Protein samples were solubilised in Laemmli buffer [23], boiled for 3-4 min and centrifuged for $2 \mathrm{~min}$ at 20,000 $\times g$ to remove insoluble materials. $5 \mu \mathrm{g}$ protein per lane was separated by SDS-PAGE $(10 \%)$ and transferred to $0.2-\mu \mathrm{m}$ nitrocellulose membrane. The blocked membranes were blotted for $2 \mathrm{~h}$ at room temperature with antibodies against the phosphorylated form of ERK1/2 $(1: 1,000) /$ total ERK1/2 $(1: 1,000)$ (Santa Cruz, Calne, UK), or for $24 \mathrm{~h}$ at $4^{\circ} \mathrm{C}$ against phosphorylated eNOS $(1 / 1,000) /$ total eNOS $(1 / 1,000)$ (Cell Signaling Technology, New England Biolabs, Hitchen, Herts, UK). The membranes were incubated with secondary antibody conjugated with $\operatorname{HRP}(1: 15,000)$, and immunoreactive bands were visualised using enhanced chemiluminescence detection reagent. The immunoreactive bands corresponding to total eNOS, phosphorylated eNOS or the combined total for the phosphorylated ERK1/2 signal on $\mathrm{X}$-ray film were quantified in densitometric analysis and expressed as an integrated density value.
Immunoprecipitation Following insulin treatment HUVECs were washed with ice-cold PBS and incubated on ice at $4{ }^{\circ} \mathrm{C}$ for $10 \mathrm{~min}$ in RIPA buffer, containing: $50 \mathrm{mmol} / 1$ Tris $(\mathrm{pH}$ 8.0), $1 \mathrm{mmol} / 1$ EDTA, $150 \mathrm{mmol} / 1 \mathrm{NaCl}, 0.1 \% \mathrm{w} / \mathrm{v}$ SDS, $1 \% \mathrm{w} / \mathrm{v} \mathrm{NP}-40,0.5 \mathrm{w} / \mathrm{v}$ sodium deoxycholate, $1 \mathrm{mmol} / 1$ PMSF, $1 \mathrm{mmol} / 1$ sodium orthovanadate, $50 \mu \mathrm{l} / \mathrm{ml}$ protease inhibitor cocktail (as described). The cells were disrupted by repeated aspiration through a 21-gauge needle and cellular debris was pelleted by centrifugation at $10,000 \times g$ for $10 \mathrm{~min}$ at $4^{\circ} \mathrm{C}$. The supernatant was pre-cleared with normal rabbit $\mathrm{IgG}$ together with protein A-agarose, and the mixture was incubated at $4^{\circ} \mathrm{C}$ for $30 \mathrm{~min}$. Centrifugation at $1,000 \times \mathrm{g}$ for $5 \mathrm{~min}$ at $4^{\circ} \mathrm{C}$ allowed a full separation of agarose beads. The supernatant (cell lysate) was transferred to two parallel fresh tubes and insulin receptor $\beta$ subunit $(\operatorname{IR} \beta)$ rabbit polyclonal antibody (Santa Cruz, Calne, UK) was added to one with normal non-immune rabbit serum added to another as immunoprecipitation control. The immune complexes were incubated overnight whilst mixing at $4^{\circ} \mathrm{C}$. Next day protein A-agarose was added, followed by additional incubation for $3 \mathrm{~h}$ at $4^{\circ} \mathrm{C}$. Immunoprecipitates were collected by centrifugation at $1,000 \times \mathrm{g}$ for $5 \mathrm{~min}$ at $4^{\circ} \mathrm{C}$. The supernatant was carefully aspirated and pellets were washed four times with RIPA buffer, each time repeating the centrifugation step. After the final wash, pellets were resuspended in Laemmli sample buffer, boiled for 2 $3 \mathrm{~min}$ and centrifuged at $20,000 \times \mathrm{g}$ for $2 \mathrm{~min}$. The resulting supernatant was separated by SDS-PAGE electrophoresis ( $5 \mu \mathrm{g}$ protein/well) and analysed by western blotting with anti-IR $\beta(1: 1,000)$ or with anti $-\mathrm{G}_{\mathrm{i} 2} \quad(1: 1,000)$ antibody (Upstate Biotechnology, Botolph Claydon, UK).

Colorimetric 3-[4,5]dimethylthiazol-2,5-diphenyltetrazolium bromide assay Since the concentration of PD098059 used ( $50 \mu \mathrm{mol} / \mathrm{l})$ has been previously reported to be cytotoxic for some cell types [24], we tested whether the viability of HUVECs was influenced by PD098059 in the present experimental conditions. Cells were seeded in 96-well plates at a density of $5 \times 10^{4}$ cells $/ \mathrm{cm}^{2}$. The following day, the culture medium was changed to medium supplemented with $50 \mu \mathrm{mol} / 1$ PD098059 (treated cells) or to regular medium with DMSO as a vehicle, at 1:1,000 dilution (control cells). Following 30-min incubation, cell viability was measured using the quantitative colorimetric 3-[4,5]dimethylthiazol2,5-diphenyltetrazolium bromide (MTT) assay [25]. The tetrazolium ring of MTT is cleaved only in active mitochondria, and so the reaction occurs only in living cells. Plates were analysed in an ELISA plate reader at $540 \mathrm{~nm}$.

Statistical analysis Statistical analyses were carried out on raw data using the Mann-Whitney test and a $p$ value of less than 0.05 was considered statistically significant. Values are expressed as means $\pm \mathrm{SD}$. For all data, $n$ represents the number of wells or dishes tested under each condition and also the results from at least two cell populations. 


\section{Results}

Nitric-oxide-dependent cyclic GMP production in HUVECs is tyrosine-kinase mediated and dependent on a pertussistoxin-sensitive G-protein Previous data from our laboratory indicate that insulin activates nitric-oxide-dependent cyclic GMP production in a manner that is dependent on time and concentration [26]. A maximal response occurs at $1 \mathrm{nmol} / \mathrm{l}$ insulin with a highly significant response observed at $5 \mathrm{~min}$ and increased production sustained for at least $1 \mathrm{~h} \mathrm{[26].}$ Thus, for all of the experiments reported in this study insulin was used at a final concentration of $1 \mathrm{nmol} / \mathrm{l}$. Incubation of HUVECs with insulin $(1 \mathrm{nmol} / \mathrm{l})$ for $5 \mathrm{~min}$ resulted in a significant increase of cyclic GMP levels above the unstimulated control level $(100 \%$ vs $35.96 \pm 14.77, p \leq 0.001)$ (Fig. 1). Previously, we proved that the observed changes in cyclic GMP reflected the increased production of nitric oxide, since the specific competitive NOS inhibitor $N$-nitro L-arginine methyl ester (L-NAME) (100 $\mu \mathrm{mol} / 1,15 \mathrm{~min})$ [27] completely abrogated the insulin-stimulated cyclic GMP level [26].

Since the insulin receptor is reported to be a tyrosine kinase receptor [28], initial experiments were carried out to confirm that nitric-oxide-dependent cyclic GMP production is dependent on tyrosine kinase in HUVECs, using the specific tyrosine kinase inhibitor erbstatin [29]. Insulin-stimulated cyclic GMP accumulation was significantly inhibited by pretreatment with $3 \mu \mathrm{mol} / \mathrm{l}$ erbstatin for $15 \mathrm{~min}$ (Fig. 1). Insulin-stimulated levels were reduced from 100 to $43.9 \pm 16.89 \% \quad(p=0.001)$, which is not sig-

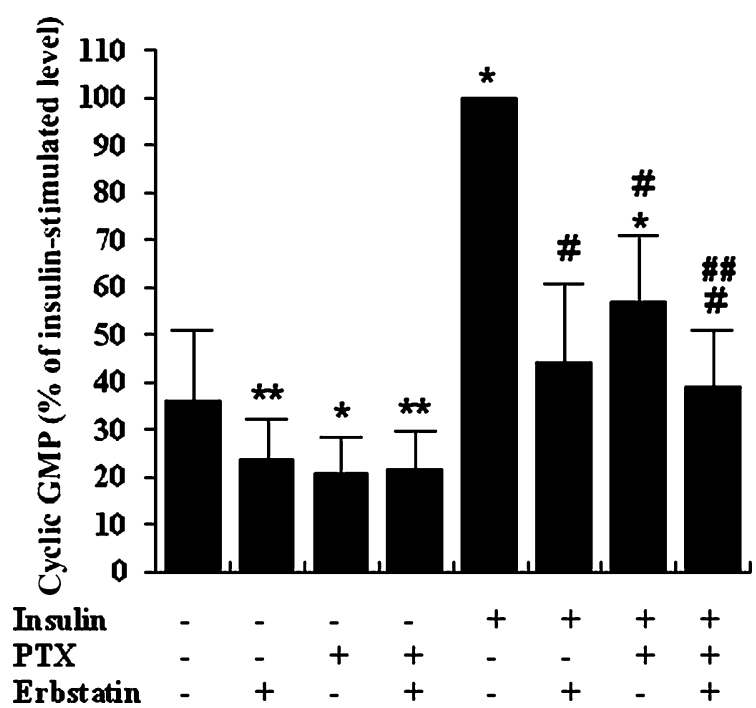

Fig. 1 The effect of pertussis toxin $(P T X)$ and erbstatin on insulinstimulated cyclic GMP production in HUVECs. Cells were preincubated for $2 \mathrm{~h}$ in the presence or absence of $500 \mathrm{ng} / \mathrm{ml} \mathrm{PTX}$, then washed and incubated for a further $15 \mathrm{~min}$ in Krebs solution in the presence of PTX and/or $3 \mu \mathrm{mol} / 1$ erbstatin, or DMSO as a vehicle and additionally for $5 \mathrm{~min}$ in buffer of the same composition with or without $1 \mathrm{nmol} / \mathrm{l}$ insulin. Cells were lysed and analysed for cyclic GMP content. Data are mean cyclic GMP levels expressed as percentage of the insulin-stimulated cyclic GMP level \pm SD $(n \geq 6)$. ${ }^{*} p<0.001$ vs control; ${ }^{* *} p=0.01$ vs control; ${ }^{*} p<0.001$ vs insulinstimulated level; ${ }^{\# \#} p=0.05$ vs insulin+PTX nificantly different to the unstimulated control value of $35.96 \pm 14.77 \%$.

In order to examine the involvement of G-proteins in insulin-stimulated nitric oxide production, HUVECs were exposed to $500 \mathrm{ng} / \mathrm{ml}$ PTX, which selectively inhibits the transmission of $\mathrm{G}_{\mathrm{i}}$-protein-mediated agonist effects [30]. Incubation with PTX for $2 \mathrm{~h}$ prior to insulin treatment reduced insulin-stimulated cyclic GMP levels by approximately 50\% (Fig. 1). Interestingly, basal cyclic GMP production in these experiments was also inhibited by PTX. When cultured cells were challenged with a combination of PTX and erbstatin, the inhibitory effect of the combined inhibitors on insulin-stimulated cyclic GMP levels was not significantly different to that of erbstatin alone, but was significantly lower than the levels observed with PTX alone (Fig. 1). This confirms that tyrosine phosphorylation of the insulin receptor is the upstream event in insulin signalling leading to nitric-oxide-dependent cyclic GMP generation.

Insulin-stimulated nitric-oxide-dependent cyclic GMP production is not dependent on PI3K Several studies have implicated PI3K in insulin-stimulated nitric oxide production $[5,11,22]$. In order to examine the role of PI3K in insulin-stimulated cyclic GMP production in our experimental model, cells were pre-incubated with the PI3K inhibitors wortmannin (100 nmol/1, $15 \mathrm{~min})$ or LY294002 (10 $\mu \mathrm{mol} / 1,15 \mathrm{~min})$ prior to insulin stimulation. Interestingly, wortmannin only reduced insulin-stimulated cyclic GMP production by $17.5 \pm 26 \% \quad(p<0.05, n=9)$ and the more specific inhibitor LY294002 had no statistically significant effect $(98 \pm 36.23 \%$ vs insulin-stimulated level of $100 \%, n=9$ ) (data not shown). Other reports have suggested that insulin-stimulated nitric oxide production is associated with phosphorylation of eNOS on $\operatorname{ser}^{1177}[31$, 32] downstream of PI3K. To investigate this relationship in the experimental system described here, serine phosphorylation of eNOS was examined in HUVECs in response to 5 -min stimulation with $1 \mathrm{nmol} / 1$ insulin. Figure 2 indicates that insulin does not stimulate eNOS phosphorylation on $\operatorname{ser}^{1177}$. The ratio of total eNOS/phosphorylated eNOS was 1:0.82 for control cells and 1:0.88 for insulintreated cells.

Insulin receptor $\beta$ and $G_{\alpha} i 2$ are not directly associated The observation that PTX significantly inhibits insulinstimulated nitric oxide production raised the possibility that $\operatorname{IR} \beta$ can transduce insulin signalling via direct dynamic regulation of a PTX-sensitive $\mathrm{G}_{\alpha} \mathrm{i}$ protein. Therefore, the possibility of a direct physical interaction between the IR $\beta$ and the $\mathrm{G}_{\alpha} \mathrm{i}$ protein in HUVECs was explored by immunoprecipitation of the $\operatorname{IR} \beta$ and western blotting of the immunoprecipitate for $\mathrm{G}_{\alpha} \mathrm{i}$. It has previously been reported that HUVECs express type $2 \mathrm{G}_{\alpha} \mathrm{i}$ [33]. In order to confirm this, an immunoblotting procedure of the whole cell lysate with an anti $-\mathrm{G}_{\alpha} \mathrm{i} 2$ antibody was performed and a specific immunoreactive band, corresponding to the molecular weight $\left(40 \mathrm{M}_{\mathrm{r}}\right)$ of $\mathrm{G}_{\alpha} \mathrm{i} 2$ was found (Fig. 3a). Initial control 
BAEC

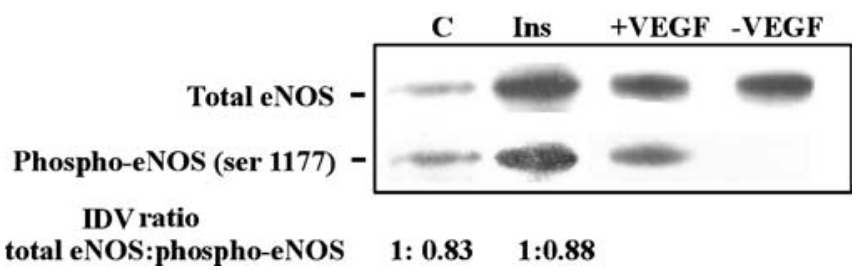

Fig. 2 Insulin (1 nmol/1) does not induce eNOS phosphorylation on ser ${ }^{1177}$ in HUVECs. HUVECs were deprived of serum and ECGS for $4 \mathrm{~h}$ and then incubated for $5 \mathrm{~min}$ in Krebs solution with $1 \mathrm{nmol} / 1$ insulin (Ins) or in medium alone as control $(C)$. Cells were then lysed, and total eNOS protein and then eNOS phosphorylated on $\operatorname{ser}^{1177}$ were assessed by western blot analysis using specific antibodies. The intensity of relevant protein bands was measured by densitometry and quantified as integrated density values (IDV), which are represented as the ratio of IDV value for total eNOS to the IDV value for eNOS phosphorylated on $\operatorname{ser}^{1177}$. Lysates of bovine aortic endothelial cells $(B A E C)$ treated with or without vascular endothelial growth factor $(V E G F)$ were included as a positive control for phosphorylated eNOS. Images shown are representative of two experiments carried out on two separate cell populations with identical results obtained on each occasion

a

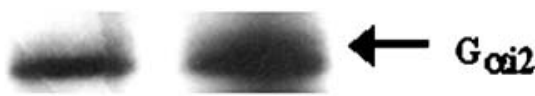

WB: anti-G $\mathrm{G}_{\text {aip }}$

b

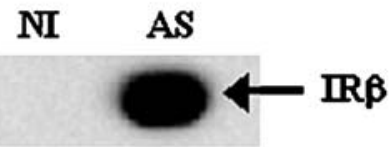

IP: anti-IRß

WB: anti-IR $\beta$

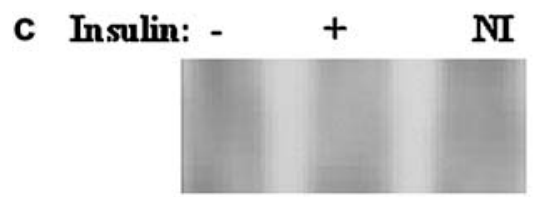

IP: anti-IR $\beta$

WB: anti- $\mathbf{G}_{\boldsymbol{\alpha} i 2}$

Fig. $3 \mathrm{G}_{\mathrm{i} 2}$ is not co-immunoprecipitated with insulin receptor $\beta$ $(I R \beta)$. a Untreated HUVECs were lysed and the cell lysate western blotted $(W B)$ with anti $-\mathrm{G}_{\alpha \mathrm{i}}$. The results from two separate cell lysates are shown. b Untreated HUVECs were lysed and immunoprecipitated $(I P)$ with either non-immune $(N I)$ serum or with anti$\operatorname{IR} \beta$ antiserum $(A S)$ and immunoprecipitates were western blotted with anti-IR $\beta$. $\mathbf{c}$ HUVECs were incubated in the presence or absence of $1 \mathrm{nmol} / \mathrm{l}$ insulin for $5 \mathrm{~min}$ as indicated. Cells were then lysed and immunoprecipitated $(I P)$ with anti-IR $\beta$ antibody or non-immune $(N I)$ control serum. Immunoprecipitates were western blotted $(W B)$ with $\mathrm{G}_{\mathrm{i} 2}$ antibody. Images shown are representative of two to three experiments carried out on three separate cell populations with identical results obtained on each occasion experiments were then carried out to confirm that IR $\beta$ could be successfully immunoprecipitated using our experimental protocol. Figure $3 \mathrm{~b}$ demonstrates that a specific immunoreactive band was detected after immunoprecipitation with the $\operatorname{IR} \beta$ antiserum, but not with the pre-immune control serum. However, $\mathrm{G}_{\alpha \mathrm{i} 2}$ could not be detected in the immunoprecipitate after immunoprecipitation with $\operatorname{IR} \beta$ in
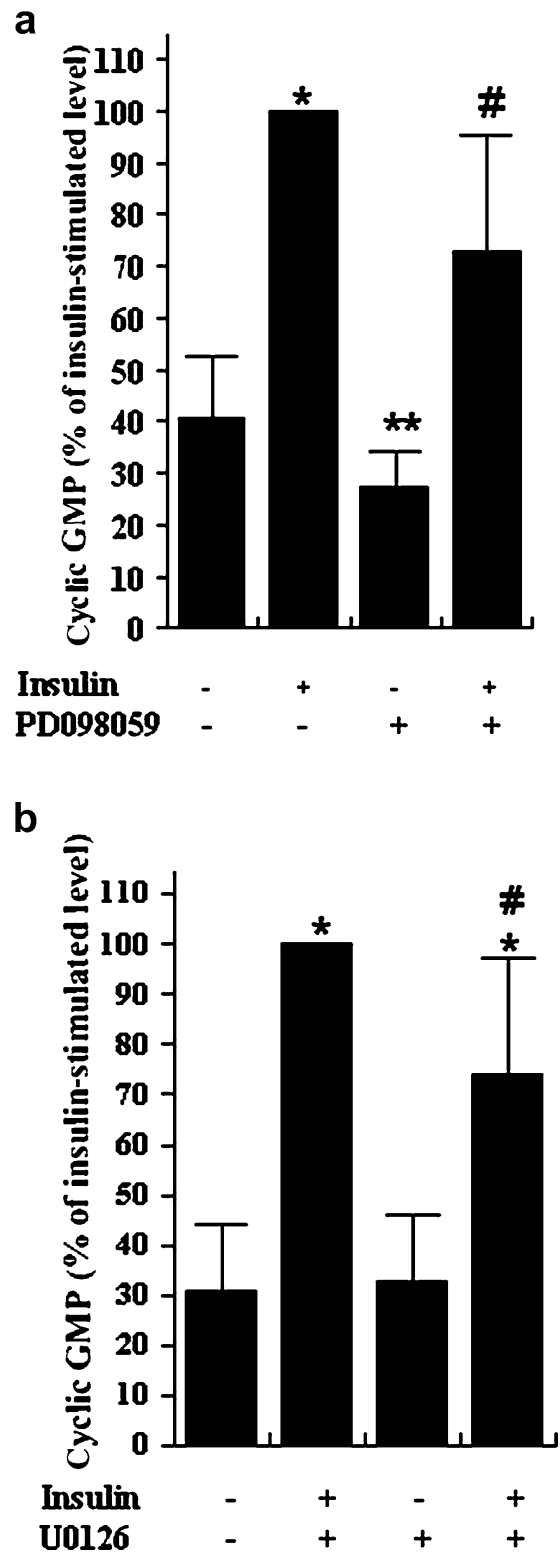

Fig. 4 The effect of PD098059 and U0126 on insulin-stimulated cyclic GMP production in HUVECs. HUVECs were preincubated for $15 \mathrm{~min}$ in the presence of $50 \mu \mathrm{mol} / 1 \mathrm{PD} 098059$ or vehicle (DMSO) (a), or for $1 \mathrm{~h}$ with $10 \mu \mathrm{mol} / 1 \mathrm{U} 0126$ or vehicle (DMSO) (b). All cells were then washed and incubated for $15 \mathrm{~min}$ in Krebs solution in the presence of PD098059/DMSO (a) or U0126/DMSO (b) and additionally for $5 \mathrm{~min}$ in buffer of the same composition $\pm 1 \mathrm{nmol} / \mathrm{l}$ insulin. Cells were lysed and analysed for cyclic GMP content. Results are presented as mean cyclic GMP levels expressed as percentage of the insulin-stimulated cyclic GMP level \pm SD $(n=9$ or 12$)$. ${ }^{*} p<0.001$ vs control; $* * p<0.05$ vs control; ${ }^{*} p=0.01$ vs insulin-stimulated level 
control, untreated cells or after insulin treatment (Fig. 3c), indicating that no direct association of $\operatorname{IR} \beta$ and $\mathrm{G}_{\alpha \mathrm{i} 2}$ could be demonstrated in HUVECs.

Insulin stimulates MAPK-dependent cyclic GMP production and ERK1/2 phosphorylation in HUVECs We then examined the possibility that MAPK activation is required for insulin-induced nitric-oxide-dependent cyclic GMP production. Pre-incubation with cell-permeable inhibitors of the ERK signalling cascade, PD098059 (50 $\mu \mathrm{mol} / \mathrm{l}$, $30 \mathrm{~min})$ [34] and U0126 (10 $\mu \mathrm{mol} / \mathrm{l}, 1 \mathrm{~h})$ [35], reduced the increase in insulin-stimulated cyclic GMP generation from $100 \%$ (insulin-stimulated level) to $72.89 \pm 22.51 \%, p<0.005$ ) for PD098059 and from 100\% (insulin-stimulated level) to $73.94 \pm 23.3 \%$ ( $p=0.005$ ) for U0126 (Fig. 4). Interestingly pretreatment with PD098059 significantly reduced basal cyclic GMP levels. However, the inhibitory effect of PD098059 on insulin-stimulated cyclic GMP remained significant even when this reduction in baseline was taken into account (data not shown). To eliminate the possibility of a potentially detrimental effect of PD098059 on cell viability, we did an MTT colorimetric cytotoxicity assay. The results demonstrated that PD098059 at $50 \mu \mathrm{mol} / \mathrm{l}$ for 30 min did not cause any statistically significant cytotoxic effect on living HUVECs $(n=3, p=1$, Mann-Whitney test, treated vs untreated cells; data not shown).

These experiments indicated a possible role for ERK $1 / 2$ in insulin-stimulated nitric oxide generation. Therefore, further studies were carried out to investigate the functional activity of ERK following insulin stimulation. Since the activation of ERK1/2 involves phosphorylation of tyrosine and threonine residues [36], activation was monitored by western blotting using an antibody specific for the phosphorylated form of the protein. Immunoblotting revealed that although levels of total ERK1/2 were unaltered by insulin treatment, insulin did induce a dramatic increase in the intensity of phosphorylated ERK1/2 (Fig. 5). This effect was evident from short $(5 \mathrm{~min})$ and prolonged $(1 \mathrm{~h})$ insulin exposure, although $1 \mathrm{~h}$ of treatment seemed to result in a larger amplitude of stimulation (Fig. 5a). The specificity of ERK1/2 activation was demonstrated by pre-incubation of endothelial cells with PD098059, which resulted in the almost complete elimination of basal and insulin-stimulated levels of phosphorylated ERK1/2 (Fig. 5b).

To examine whether nitric oxide was involved in insulininduced ERK1/2 activation, cells were incubated in the

Fig. 5 ERK1/2 phosphorylation is induced by insulin and is nitric oxide-independent. HUVECs were deprived of serum and ECGS for $16 \mathrm{~h}$ and then preincubated with: a, b control medium, $50 \mu \mathrm{mol} / 1$ PD098059 or vehicle (DMSO) for $30 \mathrm{~min}$; c control medium or $100 \mu \mathrm{mol} / 1 \mathrm{~L}-\mathrm{NAME}$ for $1 \mathrm{~h}$, followed by incubation $\pm 1 \mathrm{nmol} / 1 \mathrm{in}-$ sulin as indicated. Cells were then lysed and total ERK1/2 protein was assessed by western blot analysis using anti-non-phosphorylated total ERK1/2 antibody (a) or phosphorylation/activation of ERK1/2 was detected by western blot analysis with phospho-specific antiphosphoERK antibody $(\mathbf{a}-\mathbf{c})$. Images shown are representative of three experiments carried out on three separate cell populations with identical results obtained on each occasion. The integrated density values $(I D V)$ presented are the mean of the three experiments

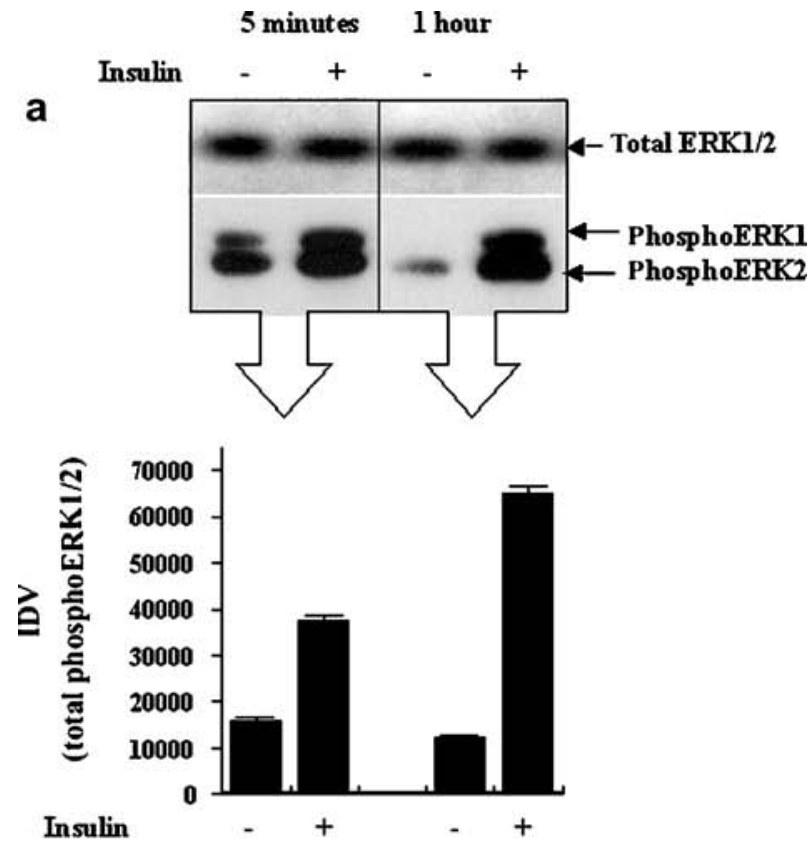

b
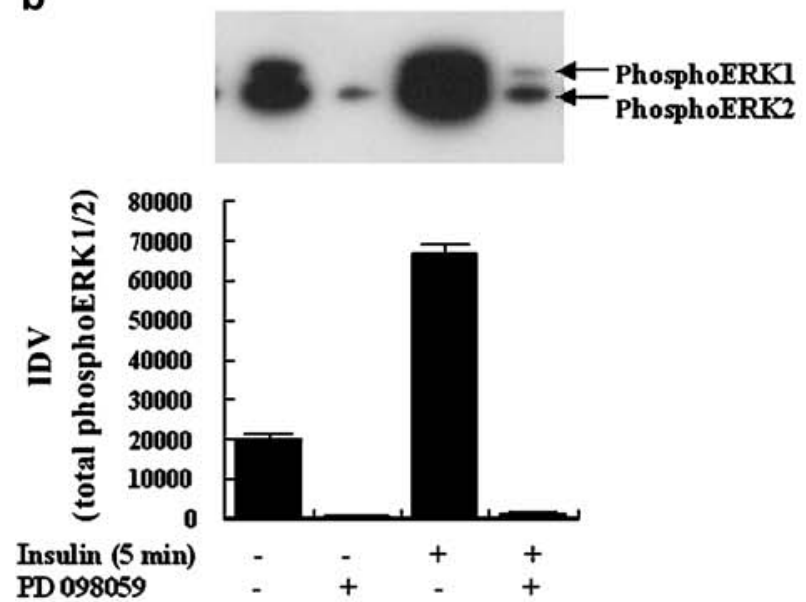

C
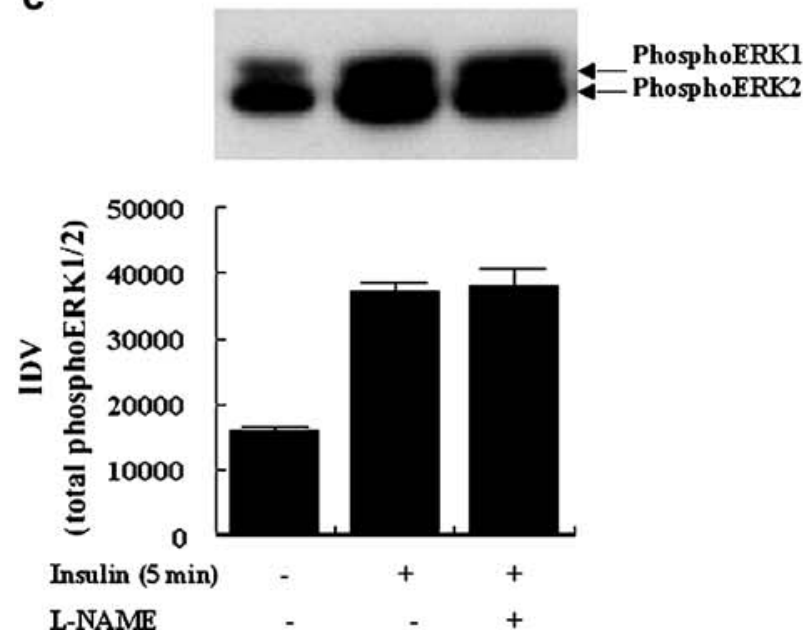
presence or absence of the NOS inhibitor L-NAME prior to insulin treatment. As demonstrated in Fig. 5c, the phosphorylated levels of ERK1/2 following insulin treatment were not altered in cells pretreated with L-NAME compared with cells stimulated with insulin following pretreatment with carrier alone (media).

ERK1/2 phosphorylation induced by insulin is sensitive to pertussis toxin In order to further dissect the elements of the signal transduction pathway upstream of insulin-induced ERK activation, the role of a $G_{i}$ protein sensitive to PTX was considered. Figure 6a illustrates that PTX completely abrogated the stimulatory effect of insulin $(1 \mathrm{nmol} / 1,5 \mathrm{~min})$ on ERK1/2 phosphorylation, and also inhibited the basal

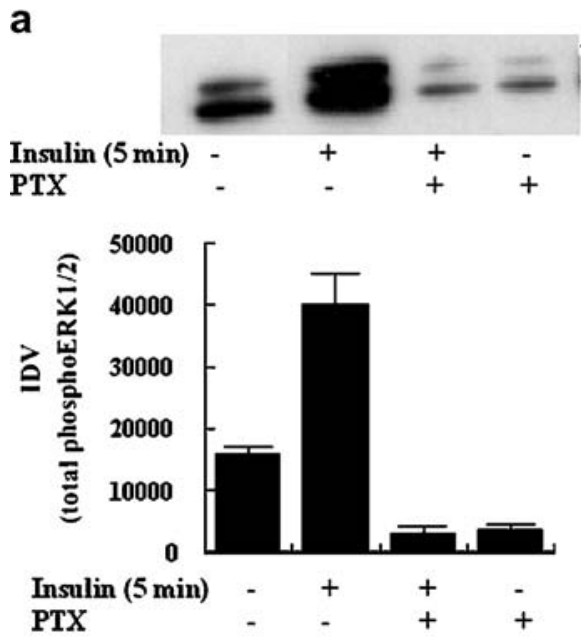

b

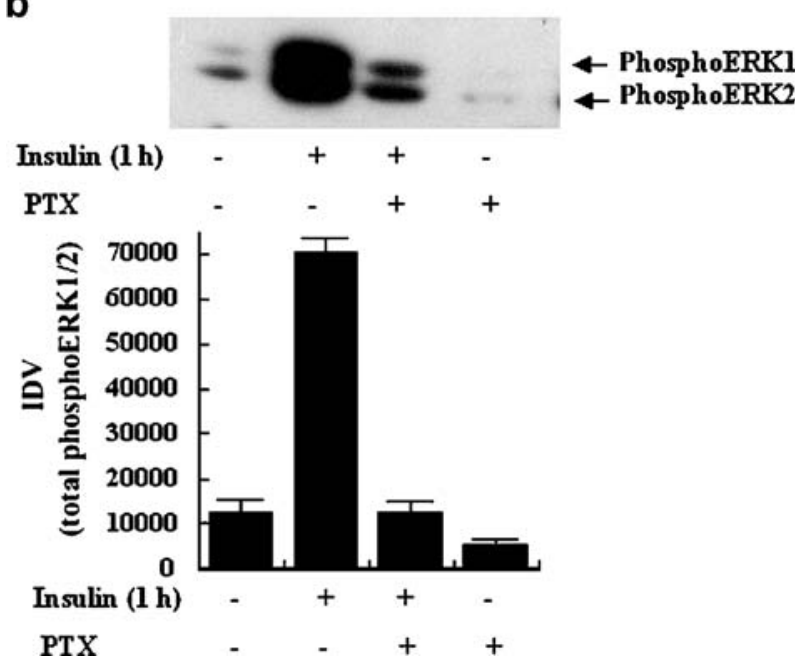

Fig. 6 The effect of pertussis toxin $(P T X)$ on insulin-induced ERK phosphorylation. HUVECs were cultured for $16 \mathrm{~h}$ in the absence of serum and ECGS, challenged for the last $2 \mathrm{~h}$ with $500 \mathrm{ng} / \mathrm{ml}$ PTX, and subsequently treated with or without $1 \mathrm{nmol} / 1$ insulin for $5 \mathrm{~min}$ (a) or $1 \mathrm{~h}$ (b) in the presence or absence of PTX. Cells were then lysed and phosphorylation/activation of ERK1/2 was detected by western blot analysis with phospho-specific anti-pERK. Images shown are representative of two to three experiments with identical results obtained on each occasion. The integrated density values (IDV) presented are the mean of experiments performed using two to three different cultures of HUVECs phosphorylation of ERK1/2. Similar results were obtained after prolonged 1-h incubation with insulin (Fig. 6b), although interestingly at this time point PTX alone reduced the baseline below those levels observed with PTX plus insulin.

\section{Discussion}

This study extends previous knowledge of the mechanism of insulin-stimulated nitric oxide production in human endothelial cells treated with physiologically relevant levels of insulin, and demonstrates for the first time that $\mathrm{G}_{\mathrm{i}}$-proteins and the activation of the ERK1/2 MAPK cascade mediate insulin-induced nitric-oxide-dependent cyclic GMP production.

Previously, work from this laboratory has reported that rapid (i.e. within $5 \mathrm{~min}$ ) nitric-oxide-dependent cyclic GMP production occurred at insulin levels closely corresponding to the range of binding and activation of insulin receptors in endothelial cells and at the concentration in normal human plasma [26]. The current study demonstrates that this insulin-stimulated nitric-oxide-dependent production of cyclic GMP is completely blocked by erbstatin, a specific inhibitor of tyrosine kinases, extending previous data using the less specific tyrosine kinase inhibitor genistein [11]. These results indicate that synthesis of nitric oxide by endothelial NOS is regulated downstream of a tyrosine kinase, presumably the insulin receptor.

The $\mathrm{G}_{\mathrm{i}}$-protein inhibitor, PTX, also significantly reduced insulin-stimulated endothelial cell nitric oxide production, clearly implicating, for the first time, a role for a pertussissensitive heterotrimeric $G_{i}$ protein downstream of the insulin receptor tyrosine kinase in this signalling pathway. There is increasing evidence that insulin signalling via several intracellular pathways may be mediated by a heterotrimeric $\mathrm{G}$ protein downstream of the insulin receptor, although the $\mathrm{G}$ protein subunit involved appears to differ depending on the cell type and the cellular response to insulin studied [17, 37-40]. Pertussis toxin sensitivity of insulin-dependent functions has previously been demonstrated for the metabolic effects of the hormone in its target tissues including the stimulation of diacylglycerol production and glucose uptake in murine myocytes $[17$, 39], and inhibition of adenylate cyclase activity in hepatocytes [40]. However, whether G-proteins that are sensitive to PTX transduce insulin-simulated vasoactive effects in human vascular endothelial cells was previously unknown. Nevertheless, a PTX-sensitive mechanism has been reported to be involved in the insulin-induced enhancement of $\alpha_{2}$-adrenergic vasorelaxation in rat aorta and in nitric oxide production in rat aorta endothelial cells although no direct nitric oxide response to insulin stimulation could be demonstrated [41].

In order to further examine the relationship between insulin and $\mathrm{G}_{\mathrm{i}}$-proteins in the experimental model used here, we examined the possibility that, similar to classic Gprotein-coupled receptors, the insulin receptor may interact directly with the G-protein. Indeed, it has been documented 
that the insulin receptor is associated with $\alpha$-subunits of non-pertussis-sensitive heterotrimeric G-proteins $\left(\mathrm{G} \alpha_{\mathrm{q} / 11}\right)$ [37] in 3T3-L1 adipocytes, with an unusual, $65-\mathrm{M}_{\mathrm{r}}$, putative GTP-binding protein $[42,43]$ in human placenta, and with $\mathrm{G}_{\alpha} \mathrm{i} 2$ in human adipocytes [44]. In the present study no association of $\mathrm{G}_{\alpha \mathrm{i} 2}$ with the insulin receptor in HUVECs could be demonstrated by co-immunoprecipitation, even though immunoblotting confirmed the presence of $\mathrm{G}_{\alpha \mathrm{i} 2}$ in these cells. Since PTX inhibits the action of all $\mathrm{G}_{\mathrm{i}}$-proteins, this implies that other $\mathrm{G}_{\alpha \mathrm{i}}$ isoforms expressed in endothelial cells may be involved in insulin receptor interactions. It is also possible that the insulin receptor, acting as a classic receptor tyrosine kinase, initiates a cascade of phosphorylation-mediated signalling events, where $\mathrm{G}_{\mathrm{i}}$-proteins act as an integrated element of the signalling chain and the activation of $\mathrm{G}_{\mathrm{i}_{\alpha}}$ could represent a downstream response to (a) putative adapter protein(s), and not a direct physical coupling to the insulin receptor. Finally, it is possible that the interaction between $\mathrm{G}_{\alpha} \mathrm{i} 2$ and the insulin receptor was too transient to be detected by the experimental methods utilised in the present study.

In insulin-triggered signalling events upstream of cell differentiation and gene expression, insulin regulates activation of the Ras/MAPK pathway. This study therefore examined whether insulin-stimulated nitric oxide production is also mediated by MAPKs, specifically ERK1/2. Insulin-mediated nitric oxide production was found to be significantly inhibited by the MEK inhibitors PD098059 and U0126, demonstrating, for the first time, that the MAPK pathway does mediate insulin-stimulated NOS activation. The stimulatory and specific effect of insulin on ERK1/2 activation was further confirmed by the finding that insulin induced a dramatic and sustained increase in expression levels of the phosphorylated forms of the enzymes. Although the prolonged $(1 \mathrm{~h})$, effect of insulin on MAPK activation in human vascular endothelial cells has recently been described [22], acute, i.e. within minutes, insulin stimulation has not been reported previously.

The reduction in intracellular cyclic GMP accumulation with the MEK inhibitors suggests that nitric oxide synthesis is a consequence of MAPK cascade activation. In order to confirm this, the effect of insulin on ERK1/2 protein phosphorylation during NOS inhibition was investigated. The results indicate that, as assessed by western blotting, insulin-stimulated ERK1/2 activation was unaffected by pretreatment of the cells with the NOS inhibitor L-NAME, suggesting that nitric oxide production is downstream of MAPK activation. Therefore, it appears that the functional relationship between nitric oxide and MAPK is not due to the stimulatory effect of nitric oxide on MAPK phosphorylation/activation. This is in contrast to previous reports in the literature indicating that nitric oxide promotes rapid cyclic-GMP-mediated MAPK activation in rat mesangial cells [45] and triggers MAPK activation induced by VEGF in postcapillary endothelium [46].

The relationship between insulin-triggered mechanisms sensitive to PTX and ERK1/2 was then investigated. Insulin-stimulated ERK1/2 activation was completely abolished by PTX, indicating that MAPK activation is downstream of heterotrimeric G-proteins in insulin signalling. The literature suggests that activation of the insulin receptor may initiate two parallel signalling pathways leading to MAPK activation: one is well characterised for insulin action and is Ras-mediated, modulating cell growth and gene expression; the other is G-protein-mediated, also involving MAPK. The second pathway, reported to be both Ras-dependent and -independent [47-49], appears to be prevalent in vascular endothelial cells as indicated by the complete inhibition of insulin-stimulated MAPK activation with PTX in the present experimental model.

The observation that PTX did not fully inhibit insulinstimulated nitric oxide production, coupled to the fact that MAPK inhibitors did not fully prevent nitric oxide production at concentrations which fully inhibited MAPK phosphorylation, suggests that other pathways are additionally activated by insulin downstream of the insulin receptor. Several studies have implicated PI3K in insulinstimulated nitric oxide production $[5,11,22]$. However, in our experimental model the PI3K inhibitors wortmannin and LY294002 had little or no effect on insulin-stimulated, nitric-oxide-dependent cyclic-GMP production. The reasons why these data do not support other reports in the literature are unknown. However, the concentration of insulin $(1 \mathrm{nmol} / \mathrm{l})$ used here to induce a robust level of nitric oxide production is at least an order of magnitude lower than those in other studies using native human endothelial cells. This raises the possibility that at low concentrations of insulin, nitric oxide production is PI3K-independent or that at low levels of insulin wortmannin- and LY 294002insensitive PI3K isoforms are involved. Since class II PI3K is known to be relatively resistant to the action of both inhibitors [50], it cannot be excluded that this class of PI3K is involved in insulin-stimulated nitric oxide production in the assay described here. It is interesting to note that other reports have suggested that insulin-stimulated nitric oxide production is associated with phosphorylation of eNOS on ser $^{1177}$ downstream of PI3K. However, in the experimental conditions described here, no phosphorylation of eNOS on $\operatorname{ser}^{1177}$ was observed. These results suggest that insulin activates multiple signalling pathways in endothelial cells, some of which are yet to be fully identified and defined.

The signalling events of eNOS activation remained largely beyond the scope of this study, but it is conceivable that MAPKs and G-proteins may be regulatory elements of insulin-induced eNOS activation, as has been shown for sphingosine 1-phosphate [51]; this requires further investigation.

In summary, these data are the first demonstration that insulin at physiologically relevant concentrations activates nitric oxide synthesis in vascular endothelial cells via Gproteins that are sensitive to PTX and are activated downstream of the insulin receptor tyrosine kinase and upstream of MAPK. In association with the described alterations in activity and expression of insulin receptors [52], MAPK [53] and heterotrimeric G-proteins $[54,55]$ in diabetes, our findings raise the possibility that disruption of insulin transduction via these signalling molecules may contribute to impairment of vasodilatory responses in diabetes. 
Acknowledgements We gratefully acknowledge the funding received from the Black family via Exeter University Foundation, the Darlington Charitable Trust, Wellcome Trust and Force Cancer Charity (Exeter). We greatly acknowledge the Maternity Unit of the Royal Devon and Exeter Hospital for providing us with umbilical cords, and Mrs Gwen Batten for technical assistance.

\section{References}

1. Nystrom FH, Quon MJ (1999) Insulin signalling: metabolic pathways and mechanisms for specificity. Cell Signal 11:563574

2. Bar RS, Hoak JC, Paecock ML (1978) Insulin receptors in human endothelial cells; identification and characterization. J Clin Endocrinol Metab 47:699-702

3. Chisalita SI, Arnqvist HJ (2004) Insulin-like growth factor-1 receptors are more abundant than insulin receptors in human micro- and macrovascular endothelial cells. Am J Physiol Endocrinol Metab 286:E896-E910

4. Sobrevia L, Nadal A, Yudilevich DL, Mann GE (1996) Activation of L-arginine transport (system $\mathrm{y}^{+}$) and nitric oxide synthase by elevated glucose and insulin in human endothelial cells. J Physiol 490:775-781

5. Zeng G, Nystrom FH, Ravichandran LV et al (2000) Roles for insulin receptor, PI3-kinase, and Akt in insulin-signaling pathways related to production of nitric oxide in human vascular endothelial cells. Circulation 101:1539-1545

6. Scherrer U, Randin D, Vollenweider P, Vollenweider L, Nicod P (1994) Nitric oxide release accounts for insulin's vascular effects in humans. J Clin Invest 94:2511-2515

7. Steinberg HO, Brechtel G, Johnson A, Fineberg N, Baron AD (1994) Insulin-mediated skeletal muscle vasodilation is nitric oxide dependent. A novel action of insulin to increase nitric oxide release. J Clin Invest 94:1172-1179

8. Baron AD, Clark MG (1997) Role of blood flow in the regulation of muscle glucose uptake. Annu Rev Nutr 17:487-499

9. Shankar RR, Wu Y, Shen H-Q, Zhu J-S, Baron AD (2000) Mice with gene disruption of both endothelial and neuronal nitric oxide synthase exhibit insulin resistance. Diabetes 49:684-687

10. Laasko M, Edelman SV, Brechtel G, Baron AD (1992) Impaired insulin-mediated skeletal muscle blood flow in patients with NIDDM. Diabetes 41:1076-1083

11. Zeng G, Quon, MJ (1996) Insulin-stimulated production of nitric oxide is inhibited by wortmannin. Direct measurement in vascular endothelial cells. J Clin Invest 98:894-898

12. Denton RM, Tavare JM (1995) Does mitogen-activated-protein kinase have a role in insulin action? The cases for and against. Eur J Biochem 227:597-611

13. Wyatt AW, Steinert JR, Wheeler-Jones CPD et al (2002) Early activation of the $\mathrm{p} 42 / \mathrm{p} 44^{\mathrm{MAPK}}$ pathway mediates adenosineinduced nitric oxide production in human endothelial cells: a novel calcium-insensitive mechanism. FASEB J 16:1584-1594

14. Moncada S, Palmer RM, Higgs EA (1991) Nitric oxide: physiology, pathophysiology, and pharmacology. Pharmacol Rev 43: 109-142

15. Neer EJ (1995) Heterotrimeric G proteins: organizers of transmembrane signals. Cell 80:249-257

16. Kilgour E, Larner J, Romero G (1992) The generation of inositolglycan mediators from rat liver plasma membranes: the role of guanine nucleotide binding proteins. Biochem Biophys Res Commun 186:1151-1157

17. Luttrell L, Kilgour E, Larner J, Romero G (1990) A pertussis toxin-sensitive G-protein mediates some aspects of insulin action in BC3H-1 murine myocytes. J Biol Chem 265:1687316879

18. Liu S, Premont RT, Kontos CD, Huang J, Rockey DC (2003) Endothelin-1 activates endothelial cell nitric-oxide synthase via heterotrimeric G-protein $\beta \gamma$ subunit signaling to protein kinase B/Akt. J Biol Chem 278:49929-49935
19. Dedkova EN, Ji X, Wang YG, Blatter L, Lipsius SL (2003) Signaling mechanisms that mediate nitric oxide production induced by acetylcholine exposure and withdrawal in cat atrial myocytes. Circ Res 93:1233-1240

20. Jaffe EA, Nachman RL, Becker CG, Minick CR (1973) Culture of human endothelial cells derived from umbilical veins. Identification by morphologic and immunologic criteria. J Clin Invest 52:2745-2756

21. Bradford MM (1976) A rapid and sensitive method for the quantitation of microgram quantities of protein utilizing the principle of protein-dye binding. Anal Biochem 72:248-254

22. Montagnani M, Golovchenko I, Kim I et al (2002) Inhibition of phosphatidylinositol 3-kinase enhances mitogenic actions of insulin in endothelial cells. J Biol Chem 277:1794-1799

23. Laemmli UK (1970) Cleavage of structural proteins during the assembly of the head of bacteriophage T4. Nature 227:680-685

24. Dudley DT, Pang L, Decker SJ, Bridges AJ, Saltiel AR (1995) A synthetic inhibitor of the mitogen-activated protein kinase cascade. Proc Natl Acad Sci U S A 92:7686-7689

25. Mosmann T (1983) Rapid colorimetric assay for cellular growth and survival: application to proliferation and cytotoxicity assays. J Immunol Methods 65:55-63

26. Konopatskaya O, Whatmore JL, Tooke JE, Shore AC (2003) Insulin and lysophosphatidylcholine synergistically stimulate NO-dependent cGMP production in human endothelial cells. Diabet Med 20:838-845

27. Murad F (1986) Cyclic guanosine monophosphate as a mediator of vasodilation. J Clin Invest 78:1-5

28. Olefsky JM (1990) The insulin receptor. A multifunctional protein. Diabetes 39:1009-1016

29. Azuma EK, Kitagawa S, You A et al (1993) Activation of the respiratory burst and tyrosine phosphorylation of proteins in human neutrophils: no direct relationship and involvement of protein kinase C-dependent and-independent signaling pathways. Biochim Biophys Acta 1179:213-223

30. Gierschik P (1992) ADP-ribosylation of signal-transducing guanine nucleotide-binding proteins by pertussis toxin. Curr Top Microbiol Immunol 175:69-96

31. Montagnani M, Chen H, Barr VA, Quon MJ (2001) Insulinstimulated activation of eNOS is independent of $\mathrm{Ca} 2+$ but requires phosphorylation by Akt at ser1177. J Biol Chem 276: 30392-30398

32. Fisslthaler B, Benzing T, Busse R, Fleming I (2003) Insulin enhances the expression of the endothelial nitric oxide synthase in native endothelial cells: a dual role for Akt and AP-1. Nitric Oxide 8:253-261

33. Voyno-Yasenetskaya A, Panchenko MP, Nupenko EV, Rybin VO, Tkachuk VA (1989) Histamine and bradykinin stimulate the phosphoinositide turnover in human umbilical vein endothelial cells via different G-proteins. FEBS Lett 259:67-70

34. Alessi DR, Cuenda A, Cohen P, Dudley DT, Saltiel AR (1995) PD 098059 is a specific inhibitor of the activation of mitogenactivated protein kinase kinase in vitro and in vivo. $\mathrm{J}$ Biol Chem 270:27489-27494

35. Davies SP, Reddy H, Caivano M, Cohen P (2000) Specificity and mechanism of action of some commonly used protein kinase inhibitors. Biochem J 351:95-105

36. Payne DM, Rossomando AJ, Martino P et al (1991) Identification of the regulatory phosphorylation sites in pp42/mitogenactivated protein kinase (MAP kinase). EMBO J 10:885-892

37. Imamura T, Vollenweider P, Egawa K (1999) G alpha-q/11 protein plays a key role in insulin-induced glucose transport in 3T3-L1 adipocytes. Mol Cell Biol 19:6765-6774

38. Kanzaki M, Watson RT, Artemyev NO, Pessin JE (2000) The trimeric GTP-binding protein $(\mathrm{G}(\mathrm{q}) / \mathrm{G}(11))$ alpha subunit is required for insulin-stimulated GLUT4 translocation in 3T3L1 adipocytes. J Biol Chem 275:7167-7175

39. Moises RS, Heidenreich KA (1990) Pertussis toxin catalyzed ADP-ribosylation of a $41 \mathrm{kDa}$ G-protein impairs insulin-stimulated glucose metabolism in BC3H-1 myocytes. J Cell Physiol 144:538-545 
40. Heyworth CM, Grey AM, Wilson SR, Hanski E, Houslay MD (1986) The action of islet activating protein (pertussis toxin) on insulin's ability to inhibit adenylate cyclase and activate cyclic AMP phosphodiesterases in hepatocytes. Biochem J 235:145149

41. Lembo G, Iaccarino G, Vecchione C et al (1997) Insulin enhances endothelial alpha2-adrenergic vasorelaxation by a pertussis toxin mechanism. Hypertension 30:1128-1134

42. Srivastava SK, Varma TK, Sinha AC, Singh US (1994) Guanosine 5'-(gamma-thio) triphosphate (GTP gamma S) inhibits phosphorylation of insulin receptor and a novel GTP-binding protein, Gir, from human placenta. FEBS Lett 340:124-128

43. Srivastava SK, Singh US (1990) Presence of an insulin receptorassociated GTP-binding protein, GIR, in human placenta. Biochem Med Metabol Biol 44:292-293

44. Krieger-Brauer HI, Medda PK, Kather H (1997) Insulin-induced activation of NADPH-dependent $\mathrm{H}_{2} \mathrm{O}_{2}$ generation in human adipocyte plasma membranes is mediated by Galphai2. J Biol Chem 272:10135-10143

45. Callsen D, Pfeilschifter J, Brune B (1998) Rapid and delayed p42/p44 mitogen-activated protein kinase activation by nitric oxide: the role of cyclic GMP and tyrosine phosphatase inhibition. J Immunol 161:4852-4858

46. Parenti A, Morbidelli L, Cui XL et al (1998) Nitric oxide is an upstream signal of vascular endothelial growth factor-induced extracellular signal-regulated kinase $1 / 2$ activation in postcapillary endothelium. J Biol Chem 273:4220-4226

47. Santiskulvong C, Sinnett-Smith J, Rozengurt E (2000) EGF receptor function is required in late G(1) for cell cycle progression induced by bombesin and bradykinin. Am J Physiol Cell Physiol 281:C886-C898
48. Nishimoto I, Hata Y, Ogata E, Kojima I (1987) Insulin-like growth factor II stimulates calcium influx in competent BALB/c 3T3 cells primed with epidermal growth factor. Characteristics of calcium influx and involvement of GTP-binding protein. J Biol Chem 262:12120-12126

49. Liebmann C (2001) Regulation of MAP kinase activity by peptide receptor signalling pathway: paradigms of multiplicity. Cell Signal 137:77-85

50. Shepherd PR, Withers DJ, Siddle K (1998) Phosphoinositide 3kinase: the key switch mechanism in insulin signalling. Biochem J 333:471-490

51. Igarashi J, Bernier SG, Michel T (2001) Sphingosine 1-phosphate and activation of endothelial nitric-oxide synthase. Differential regulation of Akt and MAP kinase pathways by EDG and bradykinin receptors in vascular endothelial cells. J Biol Chem 276:12420-12426

52. Le Marchand-Brustel Y (1999) Molecular mechanisms of insulin action in normal and insulin-resistant states. Exp Clin Endocrinol Diabetes 107:126-132

53. Purves T, Middlemas A, Agthong S et al (2001) A role for mitogen-activated protein kinases in the etiology of diabetic neuropathy. FASEB J 15:2508-2514

54. Moxham CM, Malbon CC (1996) Insulin action impaired by deficiency of the G-protein subunit $\mathrm{G}$ i alpha2. Nature 379: 840-844

55. Gawler D, Milligan G, Spiegel AM, Unson CG, Houslay MD (1987) Abolition of the expression of inhibitory guanine nucleotide regulatory protein Gi activity in diabetes. Nature 327 229-232 